Kong. Res. J. 2(2) : 123-128, 2015

ISSN 2349-2694

Kongunadu Arts and Science College, Coimbatore.

\title{
ALLELOPATHIC EFFECT OF A WEED SPECIES, CYPERUS ROTUNDUS L. AND CLEOME VISCOSA L. ON GROWTH AND DEVELOPMENT OF BLACK GRAM (VIGNA MUNGO (L.) HEPPER.)
}

\author{
Prabhakaran, J*., D. Kavitha and K. Arumugam \\ Department of Botany, Annamalai University, Annamalai Nagar- 608002. \\ *E.mail: drprabha2006@gmail.com
}

\begin{abstract}
The present study was aimed to investigate the allelopathic influence of two weed species Cyperus rotundus L. and Cleome viscosa L. against the growth of Black gram (Vigna mungo (L.) Hepper). Aqueous extracts $(5 \%, 10 \%, 25 \%, 50 \%, 75 \%$ and $100 \%$ concentrations) of whole plants of $C$. rotundus and $C$. viscosa were employed to investigate their influence on the germination and seedling growth of the black gram. The aqueous whole plants extracts (from $5 \%$ to $100 \%$ concentrations) of $C$. rotundus and $C$. viscosa exhibited an inhibitory effects on all the parameters employed in the germination percentage, root and shoot growth, fresh and dry weight, content of chlorophyll, starch, sugar and protein contents of Black gram over control. The extracts of both the weeds caused a minimum inhibition on germination and seedling growth of Black gram at $5 \%$ concentration and the intensity of inhibition increased when increased extract concentrations. The aqueous extracts of $C$. rotundus and $C$. viscosa showed an inhibitory effect on Black gram but their effect was more severe on black gram by the extract treatments of $C$. rotundus than that of $C$. viscosa.
\end{abstract}

\section{Keywords: Allelopathy, Cyperus rotundus, Cleome viscose, Vigna mungo}

\section{INTRODUCTION}

Allelopathy is an important mechanism of plant interference by the addition of plant-produced phytotoxins to the plant environment. Many of the phytotoxic substances suspected of causing germination and growth inhibition have been identified from plant tissues and soil. These substances are termed allelochemics or allelochemicals (Whittaker and Fenney, 1971). Allelochemicals refer mostly to the secondary metabolites produced by plants and are the by products of primary metabolic processes (Levin, 1976) and they have no physiological function essential for the maintenance of life. Plants produce a large variety of secondary metabolites like phenols, tannins, terpenoids, alkaloids, polyacetylenes, fatty acids and steroids, which have an allelopathic effect on the growth and development of the same plant or neighbouring plants. Considerable knowledge has been obtained concerning the chemicals involved in allelopathy, but much more is needed to answer many critical questions about this phenomenon (Narwal, 1994). One of the most worked out aspects of allelopathy in manipulated ecosystems is its role in agriculture. In this, the effects of weeds on crops, crops on weeds and crops on crops have been invariably emphasized. In addition, the possibility of using allelochemicals as growth regulators and natural pesticides promoted sustainable agriculture (Pellissier, 2000).
Some of the toxic effects of decomposition products on plants are inhibition of seed germination, stunted growth, inhibition of the primary root system and increase in secondary roots, inadequate nutrient absorption, chlorosis, slow maturation and delay or failure of reproduction (Patrick and Koch, 1958; Patrick et al., 1964). Toxins from the decomposing crop residues could affect young crop plants sown between the mature plants e.g., in relay cropping or into the stubbles of the preceding crop in multiple sequential cropping (Trenbath, 1976). Quayyam et al. (2000) reported that the Cyperus rotundus aqueous extracts and leachate of leaves and tubers significantly reduced the germination and seedling growth of rice.The study of Challa and Ravindra (1998), revealed that leachate of Echinochloa colonum inhibited the germination and seedling growth of onion, radish and knol khol. Hence the present investigation an attempt has been made to determine the allelopathic effect of two weed species i.e. Cyperus rotundus L. and Cleome viscosa L. on the growth of black gram (Vigna mungo (L.) Hepper).

\section{MATERIALS AND METHODS}

The weed plants, Cyperus rotundus L. and Cleome viscosa L. were collected from the crop fields freshly for the experimental study, whenever needed. The entire plants (root and shoot parts) used for the preparation of extracts. The extracts of whole plant were employed to study their effect on 
the germination and seedling growth of black gram (Vigna mungo (L.) Hepper.). The black gram seeds cv.TMV-1 were procured from Tamil Nadu agricultural University, coimbatore, Aduthurai. Seeds with uniform size, colour and weight were selected and stored in metal tins. All the experiments were conducted in the Department of Botany, Annamalai University.

\subsection{Preparation of aqueous extract}

Fresh plants of two weed plants were washed thoroughly and cut in to small pieces. Each of the chopped 25g samples was ground in a pestle and mortar with distilled water. Aqueous extracts thus obtained were filtered through muslin cloth and the volume was made up-to $100 \mathrm{ml}$ with distilled water. From this stock solution 25, 20, 15, 10, 5 and $2 \%$ solutions were prepared by adding distilled water. The extracts were stored in a deep freezer until they were used. Distilled water used as a control.

\subsection{Germination study}

The seeds of black gram were steeped in water to determine their viability those that floated were discarded. The viable seeds were sterilized for two minutes in $0.2 \%$ mercuric chloride $\left(\mathrm{HgCl}_{2}\right)$ solution. The seeds were then thoroughly washed with tap water. The seeds were arranged in sterilized Petri dishes of $10 \mathrm{~cm}$ diameter lined with filter paper. Each Petri dish was moistened uniformly by different concentrations of weed extracts and the distilled water was used as control. Each experiment was carried out with five replicates. The petrol dishes were covered kept at room temperature $\left(30 \pm 2^{\circ} \mathrm{C}\right)$ and were opened periodically for proper aeration. Germination percentage was recorded on $5^{\text {th }}$ day while, root and shoot length, fresh and dry weight and pigment contents (Chlorophyll-Arnon, (1949) were recorded on $8^{\text {th }}$ day after treatment.

\section{RESULTS AND DISCUSSION}

The seeds of Black gram started germinating on the third day and the maximum percentage of germination was observed on day $3^{\text {th }}$ after soaking both in the control and in treatments. Aqueous extracts of both Cyperus rotundus L. and Cleome viscosa $\mathrm{L}$. species caused a significant inhibition on the germination of the two test crops over control. The intensity of inhibition differed depending upon the organ. The extract caused an inhibition of germination and the intensity of inhibition increased as the concentration of the extract increased. The degree of inhibition of germination also increased over control.

The study of Bendall (1975) showed that the root extract of Canada thistle inhibited the germination on Trifolium subterraneum seed by $87 \%$. Similar inhibition of seed germination by weed extract was observed by different workers. The inhibitory effect of Ipomea carnea spp. Fistulosa, Cyperus rotundus, Cynodon dactylon, Echinochloa colonum, Portulaca oleracea and Lagasca mollis, on sorghum, wheat, kidney bean, rice, onion, radish and knol knoll (Jadhav et al., 1997; Challa and Ravindra, 1998), clearly supports the present findings. But on the contrary the study of Pope et al. (1985) revealed that the root exudates of Cynodon dactylon promoted seed germination in soybean plant. Most of the studies with the whole plant extract exhibited an inhibitory effect on seed germination. Whole plant extract of Trianthema portulacastrum inhibited the seed germination on soybean (Umarani and Selvaraj, 1996). This study supports the result of the present findings.

The results on the root and shoot growth of seedlings of Black gram are given in Table 3. The inhibitory effect of weed extracts of $C$. rotundus and C. viscosa on root and shoot growth of black gram was similar to their inhibitory effect on seed germination as over control. The study of Patil (1994) revealed that the leaf extracts of Glyricidia maculata L. inhibited the seedling growth of rice, sorghum, green gram and blackgram. The leaf extract of Faxinus micrantha L. inhibited the growth of root and shoot length of Raphanus sativus, Eleusine coracana, Triticum aestivum and Brassica campestris (Joshi et al., 1996). These studies are in conformity with the present findings. But on the contrary the study of Lovett and Sagar (1978) showed that the aqueous washings of leaves of Camellina sativa stimulated the growth of radicles of flax seedlings. Similarly the study of Tripathi et al. (1998) showed that the leaf extracts of Albizia procera, Tectona grandis and Acacia nilotica stimulated root and shoot length in soybean.

The fresh and dry weight of the test crop seedlings were reduced by the weed extract treatments. The degree of inhibition depends on the concentrations of the extracts. The study of Kazinczi et al. (1997) revealed that the root residues of Centaurea cyanus inhibited (50\%) the fresh weight of rape as compared to control. 
Table 1. Effect of aqueous extract of two weeds on Seedling growth $(\mathrm{cm} / \mathrm{plant})$ of Black gram

\begin{tabular}{|c|c|c|c|c|c|c|}
\hline \multirow[b]{2}{*}{$\begin{array}{c}\text { Concentration of } \\
\text { Extract }\end{array}$} & \multicolumn{3}{|c|}{ Cleome viscosa L Extracts } & \multicolumn{3}{|c|}{ Cyperus rotundus L. Extracts } \\
\hline & $\begin{array}{l}\text { Shoot Length } \\
\text { (cm) }\end{array}$ & $\begin{array}{c}\text { Root } \\
\text { Length } \\
\text { (cm) }\end{array}$ & $\begin{array}{l}\text { Leaf } \\
\text { Area } \\
\left(\mathrm{cm}^{2}\right)\end{array}$ & $\begin{array}{l}\text { Shoot Length } \\
\text { (cm) }\end{array}$ & $\begin{array}{l}\text { Root } \\
\text { Length } \\
\text { (cm) }\end{array}$ & $\begin{array}{c}\text { Leaf } \\
\text { Area } \\
\left(\mathrm{cm}^{2}\right)\end{array}$ \\
\hline Control & 20.14 & 5.22 & 3.80 & 20.14 & 5.22 & 3.80 \\
\hline ‘ 0 ' & $( \pm 1.00)$ & $( \pm 0.26)$ & $( \pm 0.19)$ & $( \pm 1.00)$ & $( \pm 0.26)$ & $( \pm 0.19)$ \\
\hline \multirow{2}{*}{$50 \%$} & 20.00 & 5.14 & 3.22 & 18.02 & 4.68 & 2.61 \\
\hline & $( \pm 1.01)$ & $( \pm 0.31)$ & $( \pm 0.20)$ & $( \pm 1.00)$ & $( \pm 0.23)$ & $( \pm 0.18)$ \\
\hline \multirow[t]{2}{*}{$1 \mathrm{no/n}$} & 19.52 & 5.01 & 3.07 & 17.80 & 4.04 & 2.50 \\
\hline & $( \pm 0.97)$ & $( \pm 0.25)$ & $( \pm 0.15)$ & $( \pm 0.89)$ & $( \pm 0.20)$ & $( \pm 0.12)$ \\
\hline \multirow[t]{2}{*}{$250 /$} & 18.55 & 4.94 & 2.93 & 16.95 & 3.08 & 2.32 \\
\hline & $( \pm 0.92)$ & $( \pm 0.24)$ & $( \pm 0.14)$ & $( \pm 0.84)$ & $( \pm 0.15)$ & $( \pm 0.11)$ \\
\hline \multirow[t]{2}{*}{$5 n 0 \%$} & 17.20 & 4.58 & 2.12 & 16.50 & 2.70 & 1.82 \\
\hline & $( \pm 0.86)$ & $( \pm 0.22)$ & $( \pm 0.10)$ & $( \pm 0.82)$ & $( \pm .0 .13)$ & $( \pm 0.09)$ \\
\hline \multirow[t]{2}{*}{$750 \%$} & 16.76 & 3.05 & 2.20 & 12.52 & 1.36 & 0.26 \\
\hline & $( \pm 0.83)$ & $( \pm 0.15)$ & $( \pm 0.11)$ & $( \pm 0.62)$ & $( \pm 0.06)$ & $( \pm 0.01)$ \\
\hline \multirow[t]{2}{*}{$1 \mathrm{nno} / \mathrm{n}$} & 15.90 & 2.64 & 0.44 & 9.02 & 0.90 & 0.19 \\
\hline & $( \pm 0.79)$ & $( \pm 0.13)$ & $( \pm 0.02)$ & $( \pm 0.45)$ & $( \pm 0.04)$ & $( \pm 0.00)$ \\
\hline
\end{tabular}

Table 2. Effect of aqueous extract of two weeds onFresh weight ((ug/plant) of Black gram .

\begin{tabular}{ccccccc}
\hline $\begin{array}{c}\text { Concentration of } \\
\text { Extract }\end{array}$ & \multicolumn{3}{c}{ Cleome viscosa L Extracts } & \multicolumn{3}{c}{ Cyperus rotundus L. Extracts } \\
\cline { 2 - 6 } Leaf & Stem & Root & Leaf & Stem & Root \\
\hline Control & 160 & 760 & 155 & 160 & 760 & 155 \\
& $( \pm 8.00)$ & $( \pm 38.80$ & $( \pm 7.75)$ & $( \pm 8.00)$ & $( \pm 38.80$ & $( \pm 7.75)$ \\
$5 \%$ & 155 & 745 & 145 & 125 & 610 & 125 \\
& $( \pm 11.50)$ & $( \pm 43.25)$ & $( \pm 9.65)$ & $( \pm 9.35)$ & $( \pm 33.25)$ & $( \pm 8.93)$ \\
$10 \%$ & 145 & 719 & 140 & 126 & 580 & 102 \\
& $( \pm 7.25)$ & $( \pm 35.95)$ & $( \pm 7.00)$ & $( \pm 6.30)$ & $( \pm 31.10)$ & $( \pm 5.10)$ \\
$25 \%$ & 118 & 610 & 135 & 109 & 563 & 99 \\
$50 \%$ & $( \pm 5.90)$ & $( \pm 30.50)$ & $( \pm 6.75)$ & $( \pm 5.45)$ & $( \pm 28.15)$ & $( \pm 4.95)$ \\
& $( \pm 0.50)$ & $( \pm 29.00)$ & $( \pm 5.45)$ & $( \pm 3.50)$ & $( \pm .24 .75)$ & $( \pm 3.90)$ \\
$75 \%$ & 75 & 470 & 65 & 59 & 427 & 59 \\
& $( \pm 3.75)$ & $( \pm 23.50)$ & $( \pm 3.25)$ & $( \pm 2.95)$ & $( \pm 2.35)$ & $( \pm 2.95)$ \\
$100 \%$ & 45 & 330 & 42 & 25 & 318 & 37 \\
& $( \pm 2.25)$ & $( \pm 16.50)$ & $( \pm 4.10)$ & $( \pm 1.25)$ & $( \pm 15.90)$ & $( \pm 1.85)$ \\
\hline
\end{tabular}

Table 3. Effect of aqueous extract of two weeds on the dry weight (ug/plant) of seedlings of Black gram (The values are mean + SE of 7 samples).

\begin{tabular}{ccccccc}
\hline \multirow{2}{*}{ Concentration of Extract } & \multicolumn{3}{c}{ Cleome viscosa Extracts } & \multicolumn{2}{c}{ Cyperus rotundus Extracts } \\
\cline { 2 - 6 } & Leaf & Stem & Root & Leaf & Stem & Root \\
\hline Control & 41 & 74 & 33 & 41 & 74 & 33 \\
& $( \pm 2.05)$ & $( \pm 3.70)$ & $( \pm 1.65)$ & $( \pm 2.05)$ & $( \pm 3.70)$ & $( \pm 1.65)$ \\
$5 \%$ & 38 & 69 & 31 & 33 & 42 & 25 \\
& $( \pm 2.13)$ & $( \pm 4.30)$ & $( \pm 1.85)$ & $( \pm 1.80)$ & $( \pm 2.50)$ & $( \pm 1.60)$ \\
$10 \%$ & $\left( \pm \frac{29}{37}\right.$ & 68 & 29 & 28 & 38 & 22 \\
& $( \pm 1.85)$ & $( \pm 3.50)$ & $( \pm 1.60)$ & $( \pm 1.60)$ & $( \pm 2.25)$ & $( \pm 1.40)$ \\
$25 \%$ & $( \pm 1.80)$ & $( \pm 3.30)$ & $( \pm 1.40)$ & $( \pm 1.50)$ & $( \pm 2.20)$ & $( \pm 1.25)$ \\
\hline
\end{tabular}




\begin{tabular}{ccccccc}
\hline $50 \%$ & 35 & 61 & 25 & 26 & 32 & 16 \\
$75 \%$ & $( \pm \underset{J\llcorner}{1.75)}$ & $( \pm 3.05)$ & $( \pm 1.25)$ & $( \pm 1.40)$ & $( \pm .2 .15)$ & $( \pm 1.00)$ \\
& $( \pm \underset{\llcorner\supset}{ }$ & $( \pm 2.85)$ & $( \pm 1.10)$ & $( \pm 1.30)$ & $( \pm 1.95)$ & $( \pm 0.95)$ \\
$100 \%$ & $( \pm 1.45)$ & $( \pm 2.75)$ & $( \pm 0.85)$ & $( \pm 1.05)$ & $( \pm 1.60)$ & $( \pm 0.7)$ \\
\hline
\end{tabular}

Table 4. Effect of aqueous extract of two weeds on chlorophyll contents (ug/g.fr.wt.) of Black gram (The values are mean \pm SE of 7 samples).

\begin{tabular}{ccccccc}
\hline $\begin{array}{c}\text { Concentration of } \\
\text { Extract }\end{array}$ & \multicolumn{3}{c}{ Cleome viscosa Extracts } & \multicolumn{2}{c}{ Cyperus rotundus Extracts } \\
\cline { 2 - 6 } Chl.-a & Chl.-b & Total chl. & Chl.-a & Chl.-b & Total chl. \\
\hline Control & 382 & 319 & 701 & 382 & 319 & 701 \\
& $( \pm 19.10)$ & $( \pm 16.05)$ & $( \pm 35.05)$ & $( \pm 19.10)$ & $( \pm 16.05)$ & $( \pm 35.05)$ \\
$5 \%$ & 371 & 311 & 682 & 265 & 241 & 521 \\
& $( \pm 22.30)$ & $( \pm 18.05)$ & $( \pm 40.35)$ & $( \pm 16.20)$ & $( \pm 15.95)$ & $( \pm 32.15)$ \\
$10 \%$ & 364 & 321 & 685 & 251 & 217 & 468 \\
& $( \pm 18.20)$ & $( \pm 15.95)$ & $( \pm 34.25)$ & $( \pm 12.55)$ & $( \pm 10.85)$ & $( \pm 23.40)$ \\
$25 \%$ & 331 & 278 & 609 & 224 & 196 & 420 \\
& $( \pm 16.55)$ & $( \pm 13.90)$ & $( \pm 30.45)$ & $( \pm 11.2)$ & $( \pm 9.80)$ & $( \pm 21.00)$ \\
$50 \%$ & 302 & 242 & 544 & 188 & 176 & 364 \\
& $( \pm 15.10)$ & $( \pm 12.10)$ & $( \pm 27.20)$ & $( \pm 9.40)$ & $( \pm .8 .80)$ & $( \pm 18.20)$ \\
$75 \%$ & 284 & 204 & 488 & 179 & 154 & 333 \\
$100 \%$ & $( \pm 14.20)$ & $( \pm 10.20)$ & $( \pm 24.40)$ & $( \pm 8.95)$ & $( \pm 7.70)$ & $( \pm 16.65)$ \\
& $( \pm 252$ & 196 & 448 & 152 & 149 & 301 \\
& $( \pm 12.60)$ & $( \pm 9.80)$ & $( \pm 22.40)$ & $( \pm 7.60)$ & $( \pm 7.45)$ & $( \pm 15.05)$ \\
\hline
\end{tabular}

The study of Umarani and Selvaraj (1996) reported that the stem and whole plant extract of Trianthema portulacastrum reduced the dry matter production on soybean. Beres and Kazinczi (1997) showed that the aqueous shoot extract of Rumex obtusefolius and Asclepias syriaca reduced the fresh and dry weight of corn. But on the other hand the root leachate of donor soybean with significantly increased the dry matter of receiver soybean (Ramamurthy and Shivashankar, 1995).

Fig.1. Allelopathic effect of aqueous extract of Cleome viscosa $L$. on seed germination percentage of Black gram

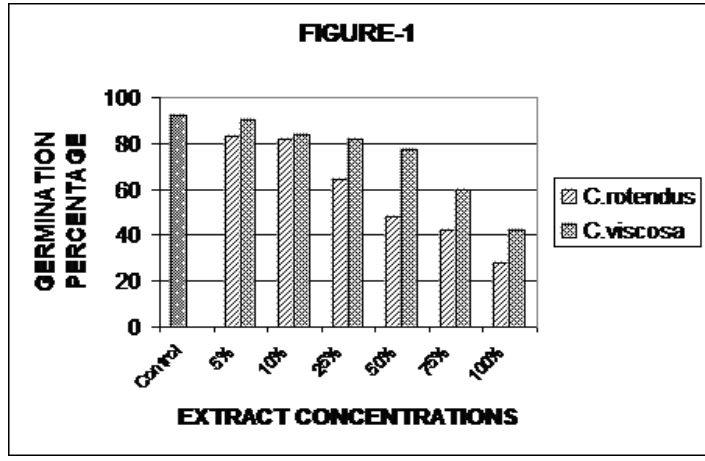

The allelopathic effect of two weed extracts exhibited a retarding effect on the contents of chlorophyll and carotenoid of black gram. The maximum chlorophyll content (Chl. a, Chl. b and total chlorophyll) was observed in control seedlings when compared to treated one. The chlorophyll content decreased as the concentration of extract increased and a maximum chlorophyll content reduction was observed at $100 \%$ treated seedlings of both the weed extracts The inhibitory effect on the chlorophyll contents was more prominent by Cyperus rotundus extract treatments than that of Cleome viscosa on black gram seedlings. Dube et al.(1979) reported that the aqueous extracts of root, stem and leaf of Parthenium hysterophorus decreased the chlorophyll production by cotyledons of radish, cabbage and cauliflower. Aqueous shoot and root extracts of Parthenium hysterophorus on mulberry (Singhal et al., 1996). Echinacea angustifolia crushed extracts of root and shoot on the seedlings of Lactuca sativa, Panicum virgatum and Sarobolus heterolepis, aqueous leaf extracts of bamboo on groundnut (Eyini et al., 1981). Leaf residue of Parthenium on Najas graminea (Pandey, 1997) aqueous leaf leachates of Euclyptus globulus in the leaves of Costus speciosus and finger millet (Konar and Kushari, 1995; Padhy et al., 2000), 
the leaf and leaflitter extracts of Quercus glauca and Q. lauotrichophora on wheat, mustard and lantil (Bhatt and Chauhan, 2000) significantly reduced the chlorophyll content of the seedlings. These studies strongly support the present findings.

The following allelochemicals present in the plant organs of Cyperus rotundus, they are 1,8cineole, 4alpha, 5alpha-oxidoeudesm-11-en-3-alphaol, Alkaloids, Alpha-cyperone, Alpha-rotunol, Betacyperone, Beta-pinene, Beta-rotunol, Beta-selinene, Calcium, Camphene, Copaene, Cyperene, Cyperenone, Cyperol, Cyperolone Cyperotundone Dcopadiene, D-epoxyguaiene, D-fructose, D-glucose, Eo, Flavonoids, Gamma-cymene, Isocyperol, Isokobusone, Kobusone, Limonene, Linoleic-acid, Linolenic-acid, Magnesium, Manganese, Mustakone, Myristic-acid, Oleanolic-acid, Oleanolic-acid-3-oneohesperidoside, Oleic-acid, P-cymol, Patchoulenone, Pectin, Polyphenols, Rotundene, Rotundenol, Rotundone, Selinatriene, Sitosterol, Stearic-acid, Sugeonol, Sugetriol (Seo et al.,2007). The pharmacological studies have shown that CV possesses various notable biological activities such as anthelmintic, antimicrobial, analgesic, antiinflammatory, immunomodulatory, antipyretic, psychopharmacological, antidiarrheal, and hepatoprotective activities. A wide variety of phytoprinciples have been isolated from C.viscosa (Mali, 2010). The differential degree of inhibitory effect two weed extracts on germination and seedling growth of Black gram may be due to the presence of various inhibitory allelochemicals at different concentrations in weed organs of C.rotundus. and C. viscosa.

\section{REFERENCES}

Arnon, D.I. (1949). Copper enzyme in isolated chloroplasts. Polypenoloxidase in Beta vulgaris. Plant Physiol., 24: 1-15.

Bendall, G.M. (1975). The allelopathic activity of California thistle (Cirsicum arvense (L.) Scop.) in Tasmania. Weed Res. 15: 77-81.

Bhatt, B.P. and D.S. Chauhan, (2000). Allelopathic effects of Quercus spp. on crops of Garhwal Himalaya. Allelopat. J. 7: 265-272.

Challa, P. and V. Ravindra, (1998). Allelopathic effects of major weeds on vegetable crops. Allelopat. J. 5: 89-92.

Dube, V.P., V.P. Singhal and S. Tyagi, (1979). Parthenium hysterophorus: Allelopathic effects on vegetable crops. Bot. Prog. 2: 62-69.
Eyini, M., H. Jayakumar and S. Pannirselvam, (1981). Allelopathic effect of bamboo leaf extract on the seedling of groundnut. Trop. Ecol. 30: 138-141.

Jadhav, P.S., N.G. Mulik and P.D. Chavan, (1997). Allelopathic effects of Ipomea carnea spp. fistulosa on growth of wheat, rice, sorghum and kidneybean. Allelopat. J. 4: 345-348.

Joshi, R.K., D. Prasad, C.B. Pande and M.S.M. Rawat, (1997). Allelopathic effect of root and bark extracts of Prunus jackuemontii on Raphanus sativus. Allelopat. J. 4: 329-334.

Kazinczi, G., J. Mikulas, K. Hunyadi, and J. Horvath, (1997). Allelopathic effects of weed on growth of wheat, sugar beet and Brassica napus, Allelopat. J. 4: 335-340.

Konar, J. and D.P. Kushari, (1995). Effect of Eucalyptus globules leachates on the growth and diosgenin content of Costus speciosus. Allelopat. J. 2: 215-218.

Levin, D.A. (1976). The chemical defences of plants to pathogens and herbivorus. Annual Rev. Ecol. Syst. 7: 121-59.

Lovett, J.V. and G.R. Sagar, (1978). Influence of bacteria in the phyllospher of Camelina sativa $\mathrm{L}$. Crentz on germination of Linum usitatissimum L. New Phytol. 81: 617-625.

Mali, R.G. (2010). Cleome viscosa (wild mustard): a review on ethnobotany, phytochemistry, and pharmacology. Pharm. Biol. 48(1):105-12.

Narwal, S.S. (1994). Allelopathy in crop production. Scientific publishers, Jodhpur, India.

Padhy, B., P.K. Patinaik and A.K. Tripathy, (2000). Allelopathic potential of Eucalyptus leaf litter leachates on germination and seedling growth of finger millet. Allelopat. J. 7: 69-78.

Pandey, D.K. (1997). Inhibition of najas (Najas graminea Del.) by parthenium (Parthenium hysterophorus L.) Allelopat. J. 4: 121-126.

Patil, B.P. (1994). Effects of Glyricidia maculata L. extracts on field crops. Allelopat. J. 1: 118-120.

Patrick, Z.A. and L.W. Koch, (1958). Inhibition of respiration, germination, and growth by substances arising during the decomposition of certain plant residues in soil. Can. J. Bot., 36: 621-647.

Patrick, Z.A., T.A. Tourroun, and L.W. Koch, (1964). Effect of crop residue decomposition products 
on plant roots. Annu. Rev. Phytopathol., 2: 267292.

Pellissier, F. (2000). What is allelopathy? Allelopathy research at the University of Savoie.

Pope, D.F., A.C. Thompson and A.W. Cole. (1985). Phytotoxicity of root exudates and leaf extracts of a nine plant species. In: The Chemistry of allelopathy: Biochemical Interactions Among plants. (A.C. Thompson, Ed.) American Chemical Society Symposium Series No. 268. pp: 220-234.

Quayyam, H.A., A.V. Malik, D.M. Leach, and C. Gottardo, (2000). Growth inhibitory effects of nutgrass (Cyperus rotundes) on rice (Oryza sativa) J. Chem. Eco. 26: 2221-2231.

Ramamurthy, V. and K. Shivashankar, (1995). Allelopathic effect of soybean, maize and sunflower. Allelopat. J. 2: 205-208.

Seo, W.G., H.O. Pae, G.S. Oh, K.Y. Chai, T.O. Kwon, Y.G. Yun, N.Y. Kim and H.T. Chung, (2007). Cyperus tincture Cyperus rotundus) from Amazon Herbs,Troplab.
Singhal, B.K., S. Chakrabaarti, T. Thippeswamy, K. Giddhar, and R.K. Datta, (1996). Parthenium hysterophorus allelopathy in mulberry. Allelopa. J. 3: 251-254.

Trenbath, B.R. (1976). Multiple Cropping (I. Papendick, Ed.). American Society of Agronomy,Madison,Wisconisin. p. 129-269.

Tripathi, S., A. Tripathi, and D.C. Kori, (1998). Allelopathic effect of extracts of Dendrocalamus strictus on germination and seedling growth of soybean. Indian J. Ecol, 25: 123-132.

Umarani, R. and J.A. Selvaraj, (1996). EffectofTrianthema portulacastrum on soybean. Allelopat. J., 3: 261-266.

Whittaker, R.H. and P.P. Feney, (1971). Allelochemics: Chemical interactions between species. Sci. 171: 757-770. 